\title{
Komparasi Literasi Informasi Generasi Baby Boomers dan Generasi X (Studi pada Pengguna Grup Whatsapp)
}

\author{
Kezia Hakim ${ }^{1}$, Gregorius Genep Sukendro ${ }^{2 *}$ \\ ${ }^{1}$ Fakultas Ilmu Komunikasi, Universitas Tarumanagara, Jakarta \\ Email: keziahakim.78@gmail.com \\ ${ }^{2}$ Fakultas Ilmu Komunikasi, Universitas Tarumanagara, Jakarta* \\ Email: geneps@fikom.untar.ac.id
}

Masuk tanggal : 15-12-2021, revisi tanggal :06-01-2022, diterima untuk diterbitkan tanggal :06-01-2022

\begin{abstract}
Information literacy is needed, especially in the midst of the era of rapid digital development. Hoaxes can spread easily in the midst of technological developments like now. Information literacy is an ability that can be a filter for all generations to protect themselves from hoax news. In this study, a test was conducted to determine whether there is a comparison or difference in information literacy in the baby boomers generation with generation $X$, especially WhatsApp group users. The population in this study are parents who are included in the baby boomers generation and generation $X$ who use WhatsApp groups. The data that has been collected is processed using SPSS version 26. The results in this study show that there is no difference in information literacy between the baby boomers generation and generation $X$, with a significance level of 0.255 .
\end{abstract}

Keywords: baby boomers generation, information literacy, $x$ generation

\begin{abstract}
Abstrak
Literasi informasi sangat dibutuhkan khususnya di tengah era perkembangan digital yang begitu pesat. Hoaks dapat menyebar dengan mudahnya di tengah perkembangan teknologi seperti sekarang. Literasi informasi adalah kemampuan yang bisa menjadi filter bagi segala lintas generasi untuk melindungi diri dari berita hoaks. Pada penelitian kali ini dilakukan uji untuk mengetahui apakah ada komparasi atau perbedaan literasi informasi pada generasi baby boomers dengan generasi $\mathrm{X}$ khususnya para pengguna grup whatsapp. Populasi pada penelitian kali ini adalah para orang tua yang termasuk dalam generasi baby boomers dan generasi $\mathrm{X}$ yang menggunakan grup whatsapp. Data yang telah terkumpul diolah menggunakan bantuan SPSS versi 26. Hasil pada penelitian kali ini menunjukan bahwa tidak ada perbedaan literasi informasi generasi baby boomers dengan generasi $\mathrm{X}$, dengan tingkat signifikansi 0.255
\end{abstract}

Kata Kunci: generasi baby boomers, generasi X, literasi informasi

\section{Pendahuluan}

Pada era sekarang, penyebaran informasi dapat dilakukan dengan mudahnya melalui banyak platform media sosial. Terlebih di saat pandemi, banyak kebijakan pemerintah yang membuat hampir seluruh masyarakat melakukan aktivitas atau kegiatannya dari rumah dan dilakukan secara daring. Mulai dari berkomunikasi, belajar, bekerja, hingga beribadah semua dilakukan secara daring. Di kutip dari McGraw Hill Dictionary media sosial sendiri merupakan sarana atau wadah yang digunakan oleh banyak orang untuk saling berinteraksi dengan orang lain dengan 
cara menciptakan informasi, menyebarkan atau berbagi informasi, serta bertukar pemikiran, informasi dan gagasan dalam sebuah jaringan sosial dan komunitas virtual (Leticia \& Rusdi, 2021).

Hingga kini varian media sosial telah berkembang banyak, mulai dari Instagram, Youtube, Whatsapp, Instagram, dan masih banyak lagi. Menurut data yang dikutip dari Beritasatu per bulan Januari tahun 2021 negara Indonesia mempunyai data pemakai internet sejumlah 202,6 juta jiwa. Dan data ini terus meningkat sebanyak 27 juta atau melonjak sebanyak 16\% dibandingkan tahun lalu. Dikutip dari Beritasatu.com media sosial terpopuler di Indonesia adalah Youtube, kemudian Whatsapp dan disusul oleh Instagram (Beritasatu.com, 2021).

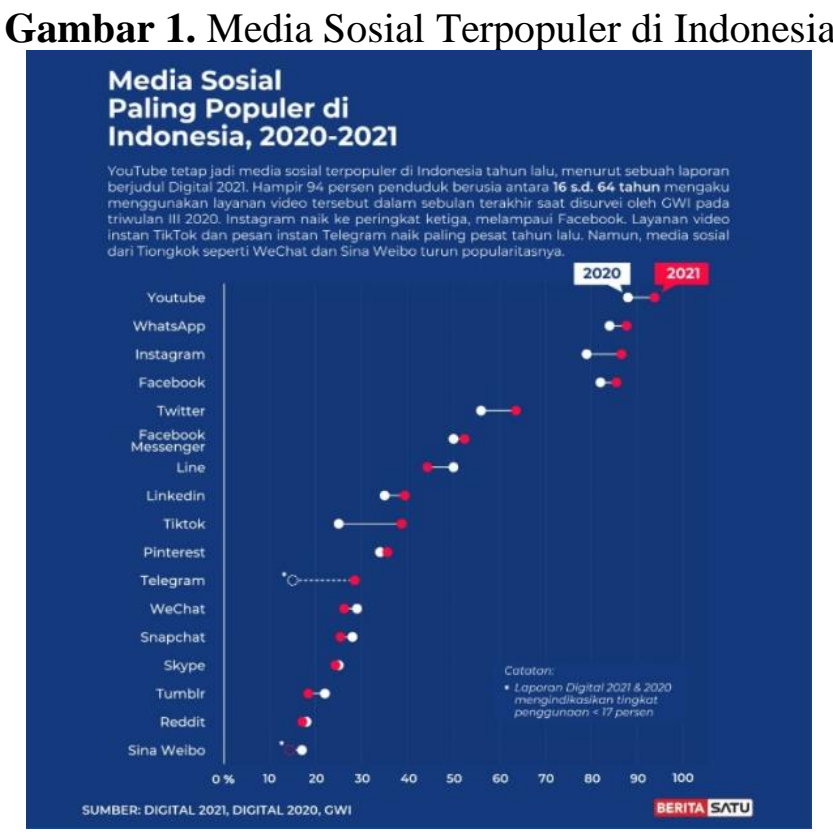

Sumber: Beritasatu.com

Dalam penelitian kali ini, penulis memilih media sosial Whatsapp hal ini didasari oleh penelitian Cempaka Fajriningtyas (2016), yang menyebutkan bahwa Whatsapp adalah aplikasi yang wajib diinstal oleh rata-rata pengguna media sosial di Indonesia (Munazar, 2020). Selain itu Menurut Karen Church dan Rodrigode Oliveira ada 7 penyebab mengapa Whatsapp marak digunakan yaitu: biaya, pengaruh sosial, tujuan pneggunaan, rasa saling keterhubungan, keterlibatan dan privasi, penggunaan teknologi, dan mekanisme pengaturan notifikasi (Munazar, 2020). Dan dapat dilihati dari data pada gambar diatas, Whatsapp menempati peringkat pertama media sosial berbasis chatting. Whatsapp sendiri merupakan sebuah aplikasi gratis berbasis chat yang menyediakan layanan untuk saling bertukar pesan (chatting) dan panggilan telepon maupun video yang aman, reliabel, dan sederhana, serta tersedia pada telepon di seluruh dunia. Namun hal ini bisa menjadi boomerang bagi masyarakat luas. Tanpa adanya filter yang tepat, penyebaran informasi yang cepat dapat sangat berbahaya.

Informasi yang disebarkan bukan hanya informasi yang bermanfaat, namun berita bohong atau hoaks pun dapat disebarkan dengan mudahnya. Hoaks dapat diartikan atau didefinisikan sebagai suatu pernyataan ataupun suatu berita yang mempunyai informasi yang tidak akurat atau tidak valid, tidak teruji kebenarannya atau berita palsu yang tidak pastian atau kebenarannya diragukan yang secara sengaja 
dibagikan untuk membuat suasana menjadi tidak kondusif, heboh dan menimbulkan ketakutan bagi banyak orang(Hasfera, 2017).

Menurut hasil publikasi yang diunggah pada Science Advance, menyatakan bahwa mereka yang tergolong usia tua (usia 65 tahun lebih) paling besar dalam menyebarkan hoaks. Bahkan jumlah besarannya mencapai 11 persen, sementara untuk usia 18-29 tahun hanya 3 persen (Tirto.com, 2019). Dapat dilihat dari salah satu kasus seorang warga Depok, Helmi Indra yang kehilangan ayahnya pada 14 Juli 2021. Diberitakan bahwa ayah Helmi meninggal akibat mempercayai hoaks Covid19 yang tersebar di grup Whatsapp keluarga (Idntimes.com, 2021).

Hal ini diakibatkan karena kurangnya kemampuan seseorang dalam memahami dan menganalisis segala informasi yang ada di media sosial. Jika dihubungkan dengan hoaks, maka bisa dikatakan masyarakat yang memiliki literasi informasi yang baik adalah mereka yang mampu mencari atau menemukan informasi, dapat membedakan, dan tidak ikut menyebar luaskan hoaks (Juditha Christiany, 2019). Literasi sangat diperlukan oleh setiap orang dan semua kalangan usia dalam menghadapi era teknologi yang terus berkembang begitu pesat. Literasi informasi bisa menjadi filter untuk seseorang tidak mudah tercemar oleh hoak. Information Literacy (Literasi Informasi) adalah kemampuan menemukan, mengevaluasi, dan juga menggunakan sebuah informasi atau berita yang dibutuhkan secara efektif (Setyaningsih et al., 2019).

Menurut Breivik dan Kuhlthau, kriteria seseorang memiliki literasi informasi sebagai berikut (Wicaksono \& Kuriawan, 2016).

a. Kemampuan dan pengetahuan. Literasi informasi dimulai dengan sebuah pemahaman mengenai sumber informasi dan alat untuk memperoleh informasi. Kemampuan ini dibutuhkan untuk menentukan bagaimana strategi dan teknik apa saja yang digunakan dalam mengakses informasi.

b. Sikap. Yang dmaksud dari hal ini meliputi bagaimana perhatian secara detail seseorang, ketekunan dan keragu-raguan seseorang dalam menerima atau mengambil informasi itu sendiri

c. Waktu dan intensitas penggunaan. Kegunaan dari kemampuan atau karakteristik ini adalah untuk mengetahui apakah seseorang menggunakan informasi secara bijak dan efektif atau tidak, digunakan pada saat dibutukan atau tidak.

d. Pengendalian kebutuhan adalah bagaimana cara seseorang mengidentifikasi suatu informasi yang akan dicari dan bagaimana orang itu memecahkan masalah dalam proses pencarian dan penggunaan informasi.

e. Literasi computer adalah bagaimana kemampuan seseorang dalam menggunakan teknologi komputer dalam kebutuhan mencari sebuah berita atau informasi.

Berangkat dari contoh kasus diatas peneliti tertarik untuk membuat penelitian mengenai literasi informasi khususnya pada generasi baby boomers dan generasi $\mathrm{x}$. Dalam penelitian kali ini penulis memberikan judul: "KOMPARASI LITERASI INFORMASI GENERASI BABY BOOMERS DAN GENERASI X (STUDI PADA PENGGUNA GRUP WHATSAPP)".

\section{Metode Penelitian}

Penelitian kali ini memiliki 2 variabel yang berbeda, yang pertama adalah variabel tergantung dan yang kedua variabel bebas. Menurutu Sugiyono (2012), 
variabel bebas adalah variabel yang menyebabkan timbulnya suatu perubahan para variabel gantung. Sedangkan variabel gantung adalah variabel yang dipengaruhi oleh variabel bebas (Evadewi \& Sukmayanti, 2013). Dalam penelitian kali ini peneliti berusaha mencari komparasi atau perbedaan literasi informasi generasi baby boomers dengan generasi $\mathrm{x}$ menggunakan pendekatan kuantitatif komparasi. Analisis komparasi adalah salah satu teknik analisis statistik yang memiliki tujuan untuk membandingkan atau mengetahu perbandingan antara suatu kelompok atau lebih (Yosani, n.d.). Berdasarkan judul penelitian dan permasalahan yang diteliti, dalam penelitian kali ini terdapat dua kelompok yaitu generasi baby boomers dan generasi $\mathrm{x}$.

Dalam penelitian kali ini, peneliti menggunakan kuisioner untuk mengumpulkan data dengan bantuan google form. Sampel dan populasi pada penelitian kali ini adalah 105 orang yang tergolong kedalam usia generasi baby boomers dan generasi $\mathrm{x}$ yang menggunaka grup whatsapp. Pada penelitian kali ini digunakan teknik sampling, yaitu purposive sampling. Purposive sampling menurut Sugiono adalah cara pengambilan sampel sumber data dengan beberapa pertimbangan tertentu, dan sampel-sampel yang dipilih adalah sampel yang diharapkan dapat memberikan informasi yang maksimal untuk menjawab setiap pertanyaan yang ada (Rusdewanti \& Gafur, 2014).

\section{Hasil Temuan dan Diskusi}

Berdasarikan hasil kuisioner yang disebarkan melalui google form kepada responden yang memenuhi kriteria, maka diperoleh data karakteristik responden yang terdiri dari pengelompokan generasi. Jumlah karakteristik responden berdasarkan pengelompokan generasi, generasi baby boomers sebanyak 44 responden atau (42\%) dan generasi x sebanyak 61 responden atau $(58 \%)$. Hal ini menandakan bahwa dalam penelitian kali ini responden yang mendominasi adalah mereka yang berada dalam kelompok generasi $\mathrm{x}$.

Penelitian kali ini memiliki 15 pertanyaan, untuk menguji data yang diperoleh pada penelitian kali ini menggunakan uji klasik untuk teknik keabsahan data, yang terdiri dari uji validitas, uji reliabilitas, uji normalitas. Untuk menentukan uji hipotesis, penulis melakukan uji homogenitas terlebih dahulu untuk melihat apakah data yang diperoleh homogen (sama) atau tidak homogen. Dalam melakukan uji hipotesis, penulis menggunakan uji Kruskal Wallis.

Tabel 1. Hasil Uji Validitas

\begin{tabular}{llll}
\hline No. & Indikator & Pearson Correlation & Keterangan \\
\hline 1. & Indikator 1 & 0.54 & \\
2. & Indikator 2 & 0.646 & Valid \\
3. & Indikator 3 & 0.596 & Valid \\
4. & Indikator 4 & 0.650 & Valid \\
5. & Indikator 5 & 0.428 & Valid \\
6. & Indikator 6 & 0.474 & Valid \\
7. & Indikator 7 & 0.520 & Valid \\
8. & Indikator 8 & 0.310 & Valid \\
9. & Indikator 9 & 0.506 & Valid \\
10. & Indikator 10 & 0.630 & Valid \\
& & & Valid
\end{tabular}


Kezia Hakim, Gregorius Genep Sukendro: Komparasi Literasi Informasi Generasi Baby Boomers dan Generasi X (Studi pada Pengguna Grup Whatsapp)

\begin{tabular}{llll} 
11. & Indikator 11 & 0.547 & Valid \\
12. & Indikator 12 & 0.332 & Valid \\
13. & Indikator 13 & 0.369 & Valid \\
14. & Indikator 14 & 0.404 & Valid \\
15. & Indikator 15 & 0.282 & Valid \\
\hline
\end{tabular}

Sumber: Hasil Olah Data Peneliti

Dalam uji Korelasi Pearson, sebuah pertanyaan pada kuesioner penelitian dianggap valid jika memenuhi kriteria berikut, nilai $\mathrm{R}$ hitung $>\mathrm{R}$ tabel (Alfian et al., 2017). Jumlah sampel penelitian kali ini adalah 105, maka peneliti menggunakan $\mathrm{R}$ tabel dengan patokan $\mathrm{N}=100 . \mathrm{R}$ tabel jika $\mathrm{N}=100$ pada signifikansi $5 \%$ adalah 0.195 .

\begin{tabular}{|c|c|}
\hline \multicolumn{2}{|c|}{$\begin{array}{c}\text { Tabel 2. Hasil Uji Reliabilitas } \\
\text { Reliability Statistics }\end{array}$} \\
\hline Cronbach's Alpha & $\mathrm{N}$ of Items \\
\hline .766 & 16 \\
\hline
\end{tabular}

Indikator yang membagi tingkatan reliabilitas dengan beberapa kriteria sebagai berikut: jika alpha Cornbach $0.8-1.0=$ maka reliabilitas dikatakan baik; 0.60.799 = maka reliabilitas dapat diterima; kurang dari $0.6=$ maka reliabilitas kurang baik (Uniati, 2014). Berdasarkan tabel diatas maka reliabilitas diterima.

Tabel 3. Hasil Uji Normalitas

Tests of Normality

\begin{tabular}{cccclll} 
& \multicolumn{3}{l}{ Kolmogorov-Smirnov } & \multicolumn{4}{l}{ Shapiro-Wilk } \\
& Statistic & Df & Sig. & Statistic & df & Sig. \\
\hline Total & .084 & 105 & .063 & .961 & 105 & .004 \\
\hline
\end{tabular}

a. Lilliefors Significance Correction

Sumber: Hasil Olah Data Peneliti

Pengujian Kolmogorov-Smirnov memiliki kriteria asymp. Sig (p) $>\alpha$, maka sebaran data berdistribusi normal. Pedoman yang digunakan adalah sebagai berikut (Pramono et al., 2021):

a. Jika suatu nilai Sig atau signifikansi lebih dari 0,05 maka distribusi data adalah dinyatakan tidak normal,

b. Jika suatu nilai Sig atau signifikansi kurang dari 0,05 distribusi data adalah dinyatakan normal

Berdasarkan tabel 3 Sig. $0.063>0.05$ maka data pada penelitian kali ini dinyatakan berdistribusi normal.

Tabel 4. Hasil Uji Homogenitas

Test of Homogeneity of Variances

\begin{tabular}{llllll} 
& & $\begin{array}{l}\text { Levene } \\
\text { Statistic }\end{array}$ & df1 & df2 & Sig. \\
\hline \multirow{2}{*}{ Total } & Based on Mean & 6.631 & 1 & 103 & .011 \\
\cline { 2 - 6 } & Based on Median & 6.626 & 1 & 103 & .011 \\
\hline
\end{tabular}




\begin{tabular}{lllll}
\hline $\begin{array}{l}\text { Based on Median and } \\
\text { with adjusted df }\end{array}$ & 6.626 & 1 & 87.671 & .012 \\
\cline { 2 - 3 } & 6.722 & 1 & 103 & .011 \\
\hline
\end{tabular}

Sumber: Hasil Olah Data Peneliti

Menurut Joko Widiyanto (2010) ada beberapa pedoman untu menentukan hasil dari uji homogenitas, pedomannya adalah sebagai berikut (Dwi et al., 2020):

a. Jika nilai signifikan berada pada $\geq 0,05$ artinya variansi dari dua atau lebih kelompok populasi data adalah sama atau disebut data homogen

b. Jika nilai signifikan berada pada $\leq 0,05$ artinya variansi dari dua atau lebih kelompok populasi data adalah tidak sama atau disebut data tidak homogen

Dari hasil pengujian diperoleh nilai signifikansi $0.11<0.05$ maka data dinyatakan tidak homogen.

Tabel 5. Hasil Uji Kruskal Wallis

Test Statistics ${ }^{\mathrm{a}, \mathrm{b}}$

\begin{tabular}{ll} 
& \multicolumn{1}{c}{ Total } \\
\hline Kruskal-Wallis H & 1.297 \\
\hline Df & 1 \\
\hline Asymp. Sig. & .255 \\
\hline
\end{tabular}

a. Kruskal Wallis Test

b. Grouping Variable: Generasi

Sumber: Hasil Olah Data Peneliti

Acuan pengambilan keputusan adalah:

a. Jika nilai asymp Sig. lebih dari 0.05 maka dapat disimpulkan tidak terdapat perbedaan $\mathrm{H} 0$ diterima dan Ha ditolak

b. Jika nilai asymp Sig kurang dari 0.05 maka dapat disimpulkan perbedaan $\mathrm{H} 0$ ditolak dan Ha diterima

Berdasarkan tabel output test statistic uji Kruskal Wallis dapat dilihat asymp Sig. berada pada angka $0.255>0.05$. Berdasarkan hasil tersebut maka dapat disimpulkan bahwa memang tidak terdapat perbedaan yang signifikan literasi informasi generasi baby boomers dengan generasi $\mathrm{X}$, maka $\mathrm{H} 0$ diterima dan $\mathrm{Ha}$ ditolak.

Hasil penelitian ini menunjukan bahwa seluruh hipotesis dalam penelitian yaitu tidak ada perbedaan literasi informasi generasi baby boomers dengan generasi $X$. Hasil dari penelitian kali ini juga mendukung penelitian sebelumnya (Maulidina \& Ridho (2020) berjudul "Internet dan Metamorfosa Generasi Digital: Analisa Perbandingan Perilaku Penyebarluasan Berita Hoax Lintas Generasi”. Hasil dari penelitian Maulidina dan Ridho adalah tidak ada perbedaan literasi informasi berdasarkan kategori usia. Semua ditentukan oleh kualitas yang bersangkutan dalam mengkonsumsi informasi dan berita, kemampuan menguasai teknologi, dan keluasan pengetahuan dan juga wawasannya.

Jika dilihat dari lintas generasi memang tidak ditemukan perbedaan literasi informasi yang signifikan antara generasi baby boomers dengan generasi x. Namun dalam penelitian kali ini juga meneliti hubungan antara jenis kelamin dengan literasi informasi. Dan menariknya memang terdapat hubungan antara jenis kelamin dengan literasi informasi. 
Kezia Hakim, Gregorius Genep Sukendro: Komparasi Literasi Informasi Generasi Baby Boomers dan Generasi X (Studi pada Pengguna Grup Whatsapp)

Tabel 6. Hasil Output Chi-Square Test Chi-Square Tests

\begin{tabular}{lccr} 
& Value & Df & $\begin{array}{c}\text { Asymptotic } \\
\text { Significance } \\
\text { (2-sided) }\end{array}$ \\
\hline Pearson Chi-Square & $9.569^{\mathrm{a}}$ & 4 & .048 \\
\hline Likelihood Ratio & 9.845 & 4 & .043 \\
\hline Linear-by-Linear Association & 4.872 & 1 & .027 \\
\hline N of Valid Cases & 105 & & \\
\hline
\end{tabular}

a. 3 cells (30.0\%) have expected count less than 5. The minimum expected count is .63 .

Sumber: Dokumentasi Pribadi (2021)

Pada tabel di atas penulis melakukan uji crosstab antara jenis kelamin dengan dimensi skill and knowledge dengan perolehan angka $0.048<0.05$. Ada hubungan antara jenis kelamin atau gender dengan dimensi skill and knowledge, yaitu pengetahuan mengenai sumber informasi dan alat yang digunakan untuk memperoleh informasi tersebut. Hasil tersebut dapat dipahami karena memang terdapat perbedaan karakteristik pada otak yang dipengaruhi oleh jenis kelamin sesuai dengan penelitian Amin (2018).

\section{Simpulan}

Berdasarkan dari uji hipotesis sebelumnya, maka hasil penelitian yang telah diperoleh dan dijelaskan oleh penulis mengenai komparasi literasi generasi baby boomers dengan generasi $\mathrm{X}$ maka dari hasil yang didapat tersebut penulis menyimpulkan bahwa tidak terdapat perbedaan literasi informasi yang signifikan generasi baby boomers dengan generasi X. Meski lahir pada waktu yang berbeda dan generasi yang berbeda, namun tidak ada perbedaan literasi informasi pada penelitian kali ini. Hal ini dapat disebabkan karena generasi baby boomers dan generasi $\mathrm{x}$ merupakan sama-sama generasi digital immigrant. Namun temuan lain dari penelitian kali ini adalah ditemukan adanya hubungan antara jenis kelamin dengan literasi informasi.

Bagi peneliti selanjutnya, diharapkan dapat menambah faktor-faktor apa saja yang memiliki pengaruh terhadap literasi informasi yang dimiliki seseorang, sehingga dapat memperoleh hasil penelitian yang lebih mendalam dan juga dapat diterima oleh semua kalangan usia.

\section{Ucapan Terima Kasih}

Peneliti ingin mengucapkan terima kasih kepada Fakultas Ilmu Komunikasi Universitas Tarumanagara, narasumber, serta semua pihak yang turut membantu peneliti sehingga penelitian ini dapat diselesaikan.

\section{Daftar Pustaka}

Amin, M. S. (2018). Perbedaan Struktur Otak dan Perilaku Belajar Antara Pria dan Wanita; Eksplanasi dalam Sudut Pandang Neuro Sains dan Filsafat. Jurnal Filsafat Indonesia, 1(1), 38-43. https://ejournal.undiksha.ac.id/index.php/JFI/article/view/13973 
Cerita Helmi Kehilangan Ayah yang Dipicu Hoaks COVID-19. (n.d.). Retrieved August 18, 2021, from https://www.idntimes.com/news/indonesia/santidewi/kisah-helmi-indra-ayah-saya-meninggal-karena-percaya-hoaks-covid

Data: Ini Media Sosial Paling Populer di Indonesia 2020-2021. (n.d.). Retrieved November 21, 2021, from https://www.beritasatu.com/digital/733355/dataini-media-sosial-paling-populer-di-indonesia-20202021

Dwi, Y., Lulu', A.;, Mufarokha, I., Williana, ;, \& Matematika, P. (2020). IMPLEMENTASI MODEL PEMBELAJARAN CTL TERHADAP KEMAMPUAN PEMECAHAN MASALAH SISWA KELAS XI SMK GONDANG WONOPRINGGO. ProSANDIKA UNIKAL (Prosiding Seminar Nasional Pendidikan Matematika Universitas Pekalongan), 1, 83-88. https://proceeding.unikal.ac.id/index.php/sandika/article/view/394

Evadewi, R. K. P., \& Sukmayanti, K. M. L. (2013). Kepatuhan Mengonsumsi Obat Pasien Hipertensi Di Denpasar Ditinjau Dari Kepribadian Tipe A Dan Tipe B. Jurnal Psikologi Udayana, 1(1), 1,32-42. https://fmipa.umri.ac.id/wpcontent/uploads/2016/09/Kartika-Kepatuhan-pasien-hipertensiminumobat.pdf

Hasfera, D. (2017). Mewujudkan generasi literat nelalui perpustakaan perguruan tinggi (Tantangan UIN Imam Bonjol Padang Menghadapi HOAX). 9.

Juditha Christiany. (2019). Literasi Informasi Melawan Hoaks Bidang Kesehatan di Komunitas Online. Jurnal ILMU KOMUNIKASI, 16(1).

Leticia, L., \& Rusdi, F. (2021). Pengaruh Personal Branding Felicya Angelista di Instagram Terhadap Loyalitas Pelanggan Produk Scarlett Whitening. Prologia, 5(2), 329-334. https://journal.untar.ac.id/index.php/prologia/article/view/10204

Masalah Orangtua: Gemar Membagi Hoaks di Medsos dan WhatsApp. (n.d.). Retrieved September 11, 2021, from https://tirto.id/masalah-orangtua-gemarmembagi-hoaks-di-medsos-dan-whatsapp-decZ

Maulidina, R., \& Ridho, K. (2020). Internet dan Metamorfosa Generasi Digital: Analisa Perbandingan Perilaku Penyebarluasan Berita Hoax Lintas Generasi. Jurnal Studi Jurnalistik, 2(2), 133-145. https://doi.org/10.15408/jsj.v2i2.18920

Munazar, R. (2020). HUBUNGAN ANTARA GENERASI X, Y, DAN Z DENGAN LITERASI DIGITAL TERHADAP HOAKS. https://repository.arraniry.ac.id/id/eprint/15560/1/Rizky\%20Munazar\%2C\%20150401026\%2C\% 20FDK\%2C\%20KPI\%2C\%20085359827181.pdf

Pramono, A., Tama, T. J. L., \& Waluyo, T. (2021). ANALISIS ARUS TIGA FASA DAYA 197 KVA DENGAN MENGGUNAKAN METODE UJI NORMALITAS KOLMOGOROV-SMIRNOV. Jurnal RESISTOR (Rekayasa Sistem Komputer), 4(2), 213-216. https://doi.org/10.31598/JURNALRESISTOR.V4I2.696

Rusdewanti, P. P., \& Gafur, A. (2014). PENGEMBANGAN MEDIA PEMBELAJARAN INTERAKTIF SENI MUSIK UNTUK SISWA SMP. Jurnal Inovasi Teknologi Pendidikan, 1(2), 153-164. https://doi.org/10.21831/TP.V1I2.2526

Setyaningsih, R., Abdullah, A., Prihantoro, E., \& Hustinawaty, H. (2019). MODEL PENGUATAN LITERASI DIGITAL MELALUI PEMANFAATAN ELEARNING. https://jurnalaspikom.org/index.php/aspikom 
Kezia Hakim, Gregorius Genep Sukendro: Komparasi Literasi Informasi Generasi Baby Boomers dan Generasi X (Studi pada Pengguna Grup Whatsapp)

Uniati, M. I. (2014). LEARNING ORGANIZATION, KOMITMEN PADA ORGANISASI, KEPUASAN KERJA, EFEKTIVITAS PENERAPAN SISTEM ISO DAN DAMPAKNYA TERHADAP KINERJA ORGANISASI (STUDI KASUS STAF ADMINISTRASI UK PETRA SURABAYA). Jurnal Manajemen Pemasaran, 8(1), 27-38. https://doi.org/10.9744/PEMASARAN.8.1.27-38

Yosani, C. (n.d.). Teknik Analisis Kuantitatif 1 TEKNIK ANALISIS KUANTITATIF. 